https://helda.helsinki.fi

\title{
Rights, History, Critique
}

\section{Koskenniemi, Martti}

Oxford University Press

2018-05

Koskenniemi , M 2018 , Rights, History, Critique . in A Etinson (ed.), Human Rights : Moral or Political? . Oxford University Press , Oxford . https://doi.org/10.1093/oso/9780198713258.003.0002

http://hdl.handle.net/10138/325018

https://doi.org/10.1093/oso/9780198713258.003.0002

unspecified

acceptedVersion

Downloaded from Helda, University of Helsinki institutional repository.

This is an electronic reprint of the original article.

This reprint may differ from the original in pagination and typographic detail.

Please cite the original version. 


\title{
RIGHTS, HISTORY, CRITIQUE
}

\author{
Martti Koskenniemi
}

What are human rights? Where do they come from? How can we know them, or know if we "have" them? (And what does "having a right" mean?) Any discussion of the nature or role of rights tends very rapidly to lead to questions that seems soluble only by taking a stand on some pretty tough issues that have been debated for at least 2000 years of Western political thought. Although some do suggest, or at least imply, that we are now finally in a position to give a credible response to questions such as those above, most would think it ridiculous to expect that legitimate recourse to right-talk is allowed once this has actually taken place. Surely it is possible to talk meaningfully of rights even in the absence of any firm philosophical founding for such talk. Here as elsewhere, Gelassenheit - just "letting it be" - has much to speak for itself. There is much in the world that we do although we cannot quite explain why we do so. Perhaps all we can say about rights, at least for now, is that something like them need to be supposed for the other things we do or say in the world to make sense. It is true that this makes them articles of a pragmatic faith, referring back to nothing grander than the effortless intimacy we have with our practices. But why would this be wrong? Is not asking those grander questions just to have missed the postmodern boat? ${ }^{1}$

But even if the kind of unthinking, pragmatic faith might sometimes be useful, it is not always available. Famously, "faith" is not born out of a wish we had it. Once those "hard" questions have been posed, it is difficult to forget them. The genie is out of the bottle and we find ourselves struggling with it. This may not happen as long as we talk with those with whom we agree. But often we use rights in contexts of disagreement, to defend entitlements that have been denied or to attack claims that seem unfounded. Rights-language has distributive consequences. In an otherwise utilitarian policy-environment, rights indicate preferences that cannot be overridden by whatever net benefits a policy might have. This is why everyone has a great interest in having their preference parade as rights. Without an authoritative list, however, there is no limit to the process whereby preferences are translated into rights. In the end, all social conflict will appear as rights-conflict. At that point, it begins to seem seems imperative to find an answer to questions such as: "What is a "right" (in contrast to mere "preference")? How do we know them? Do they exist in some hierarchy? What values determine their position?" The relaxed attitude "if it works do not fix it" no longer suffices. Instead an urgent response is called for to such questions "Works for whom? With what cost?"

\footnotetext{
${ }^{1}$ Marie-France Dembour has usefully identified four approaches to human rights - thinking of them as "natural" or as aspects of "protest", part of a "deliberative" politics or simply a "discourse". Only the first two, "believe in" rights while the latter use rights as policy-instruments. Who Believes in Human Rights? Reflections on the European Convention (Cambridge University Press 2006), 232-271.
} 
A return to philosophy will hardly prove helpful. The twentieth century has not been kind to the idea that the resolution of social conflicts should take place by abstract reasoning. Hence, I think, increasing recourse to anthropology and sociology in rights-analysis. ${ }^{2}$ And hence the impressive recent surge of histories of rights. ${ }^{3}$ It is this last move that I shall adopt and whose significance I shall discuss briefly in this essay. Perhaps, if rights cannot be grounded on faith or philosophy, we might at least think of them historically, as part of the way a period looks at things. Much new historical work has looked for the origin of our present obsession with individual (human) rights. That origin has been found in different periods. Were "human rights" part of Roman (civil) law?4 Or did they only emerge in the process or recovery of that law in the $12^{\text {th }}$ and $13^{\text {th }}$ centuries"? Did they belong to Canon law or emerge only with the nominalist attack upon Thomistic rationalism? ${ }^{5}$ Should the first significant articulation of the idea of human rights be credited to the Spanish scholastics? ${ }^{6}$ Or would it be more appropriate to focus on protestant ideas about resistance to authority in the $16^{\text {th }}$ century? ${ }^{7}$ Should Hobbes or Grotius be heralded - for good or ill - as the intellectual fathers of the idea of individual (natural) rights? ${ }^{8}$ Or did the idea of such rights emerge only with $18^{\text {th }}$ century enlightenment, the American Bill of Rights (1776) or the French Déclaration des droits de l'homme et du citoyen (1789)?99 What about the connection between the emergence of human rights and the abolition of slavery, or the rise of the various humanitarian movements in the $19^{\text {th }}$ century? 10

\footnotetext{
2 See e.g. Sally Engle Merry \& Mark Goodale (eds), The Practice of Human Rights: Tracking Law Between the Global and the Local. Cambridge University Pres 2007); David Kennedy, The Rights of Spring (Princeton University Press 2008); Miia Halme-Tuomisaari, Human Rights in Action. Learning Expert Knowledge (Leiden, Brill 2010);

3 For a useful overview, see Samuel Moyn, 'Substance, Scale, and Salience: The Recent Historiography of Human Rights', 8 Annual Review of Law and Social Science (2012), 123-140. ,

${ }^{4}$ See e.g. Jakob Giltaj, Menschenrechten in het romersche recht? (Nijmegen, Wolf 2011).

5 The view that rights emerged in the context of the Franciscan poverty dispute within the Catholic debates on natural law has been powerfully made in Brian Tierney, The Idea of Natural Rights. Studies in natural Rights, Natural Law and Church Law 1150-1625 (Grand Rapids Eerdmans 1997). See also Charles J. Reid Jr. 'The Canonistic Contribution to the Western Rights Tradition: An Historical Inquiry', 33 Boston College Law Review (1991-92), 37-92. Against the (now old) view that subjective rights emerged with Ockham and the "moderns", Peter Garnsey has concluded that "Romans did possess the concept of property rights and individual rights in general", Thinking about Property. From Antiquity to the Age of Revolution (Cambridge University Press, 2007), 194. This is not the place to examine these arguments. Instead, there is reason to emphasize, from a legal point of view, the ease with which positions about objective law can be re-written in terms of the subjective rights of those who are to benefit from the enforcement of (objective) law. This is why there is in fact no "paradox" in the way conciliar "collectivism" could produce a theory of individual rights - as little in fact that rights played a large role in the emergence of statehood. For the paradox, see Tierney, The Idea of Natural Rights, supra note_, 208-216.

${ }^{6}$ See Annabel Brett, Liberty, Right and Nature. Individual Rights in Later Scholastic Thought (Cambridge University press 1997).

${ }^{7}$ See e.g. John Witte, 'Rights, Resistance, and Revolution in the Western Tradition: Early protestant Foundations', 26 Law \& Hist. rev. (2008), 545-570.

8 This is the view of that most insistent critic of rights-individualism, Michel Villey. See e.g. his Le droit et les droits de l'homme (Paris PUF 1983).

${ }^{9}$ See Lynn Hunt, Inventing Human Rights. A History (New York, Norton 2007). See also the Jellinek - Boutmy debate regarding the proper origin of rights in either the American or French revolutions, see Duncan Kelly, 'Revisiting the Rights of Man: Georg Jellinek on Rights and the State', 22 Law \& Hist. Rev. (2004), 493-529. 10 See Jenny S. Martinez, The Slave Trade and the Origin of International Human Rights Law (Oxford University Press 2012). But see also Samuel Moyn, 'Of Deserts and Promised Lands. The Dream of Global justice', The Nation (March 19, 2012).
} 
Others have argued that there is no such long trajectory of "rights" passing through history. They have suggested that rights should be seen as part of $20^{\text {th }}$ century institutional politics - perhaps that it "began" in the debates on minority protection within the League of Nations, or the passing of the 1948 Universal Declaration on Human Rights (UDHR), and as a reaction to Hitlerite racial aggression. ${ }^{11}$ Others have claimed that our present rights talk should be seen in even more recent light - as an offshoot of 1970s cold war strategies or as the post-cold effort to construct an ideological foundation to 1990s institutional developments in international human rights law. ${ }^{12}$

The turn to history in order to understand rights today is surely useful, though not as an effort to search the origin for our present rights-practices. That would presuppose the self-evidence of our present rights - the very starting-point that was questioned - and reduce the past into an immature "predecessor". History is useful not because it "originates" or "foreshadows" present practices but because it provides illustrations of the ways in which a political vocabulary (such as rights-language) can be used for the accomplishment of different tasks. There are serious interpretative questions about the meaning and relations of "natural rights", "individual rights", "subjective rights" and "human rights" in different periods. They resemble, but are also different. While political philosophy seeks to clarify the differences and resemblances in its pursuit of a good rights-vocabulary, history, or at least conceptual history, seeks to locate rights in the contexts of contestation where they have been used to defend or attack distributive schemes and claims of jurisdiction. History does not resolve today's problems. But it may relieve us from the anxiety that loss of faith in rights as providing a ready-made set of answers to social conflict may have engendered. It brings them down from conceptual abstractions and shows them as parts of a human world where they give shape and plausibility to different agendas. What we should think of them, or how they might be implemented in a world scarce resources will still remain a matter of political judgment.

To answer the question "what are human rights?" without entangling in endless philosophical conundrums it is possible to focus on the use of the rights-idiom in the practical contexts where political or professional actors have had recourse to it. They may have done this to make a claim, to support a preference or to attack an adversary; they may have referred to rights to defend or challenge some use of power. Below I will lay out some of such uses. But I recognize also the limits of this type of contextual history. What is the relevant "context"? Is it that of scholars and jurists or that of political, military or economic power? Should we look at agents or structures? In making such choices, , contextual history approaches its rivals by beginning to think about history normatively - singling out more or less relevant aspects of the past by reference to contemporary concerns. I do not think there is any closure: norms and histories feed into each

\footnotetext{
11 Makau W Mutua, Human Rights. A Political and a Cultural Critique (University of Pennsylvania Press 2002), 15-17

12 For an instant classic, see Samuel Moyn, The Last Utopia. Human Rights in History (Harvard University Press, 2010).
} 
other endlessly. But I think that emphasis on history is specifically needed in the human rights field to rid it from its persistent ideological commitment to thinking of by reference to some timeless human essences enshrined in "universal" and inalienable" norms, a commitment sometimes genuine but often contrived and cynical.

\section{I: HOW TO DO THINGS WITH RIGHTS - THREE EXAMPLES}

A. Rights in a Counter-Reformation mode: Spanish $16^{\text {th }}$ century

Three challenges faced unified Spain at the turn of the $16^{\text {th }}$ century. Expansion in the Americas was not only hugely costly but posed serious ideological and religious questions about the expanse of the world and the striking differences in the beliefs and ways of life of its populations. Problems from the management of a transcontinental empire were accompanied by concerns of conscience relating to the expansion of trade and commercial culture inside Europe that were impossible to alleviate within prevailing religious doctrines. The rapid spread of Protestantism in the Habsburg realm suggested that neither set of questions was efficiently resolved by the Church or prevailing ideas of Christian rulership.. But Spain was also home to Europe's intellectual powerhouse, the University of Salamanca, where scholars such as Francisco Vitoria (1485/92?-1545) and Domingo de Soto (1494-1560) applied the most up-to date humanist teachings to respond to the challenges faced by their monarch who was in 1519 crowned Emperor and Dominus mundi.

The Salamanca scholars were regularly consulted by the Emperor, members of the imperial elite and leading merchants about the concerns raised by the novel practices. ${ }^{13}$ To strengthen the Church's intellectual and moral leadership it was important that their responses would fit with inherited religious views but also not outlaw territorial and commercial expansion or complicate the struggle against Protestantism. At the heart of their responses to problems about the government of the "Indies", about just war and about the ethics of commerce (trade, banking, insurance and so on) was a notion of subjective right, dominium in its two related forms, sovereignty and property (dominium jurisdictionis and dominium proprietatis). Humans had been created free, Vitoria and Soto argued, which meant they possessed dominium in actionum suarum - dominion over themselves and their actions. ${ }^{14}$ This enabled them to set up social institutions to lead good and virtuous lives. God had originally foreseen that humans would live in peace, sharing all things in common. With the Fall, however, this had became impossible. There was

\footnotetext{
13 I have discussed these in detail in my 'Empire and International Law: The Real Spanish Contribution', 61 University of Toronto Law Journal (2011), 1-36.

${ }^{14}$ See See Franciso de Vitoria, Comentarios a la Secunda secundae de Santo Tomás (Edition preparada por Vicente Beltrán de Heredia (Salamanca, 1934/1952) Tomo III, Q 62 A 10-11 (69-71) and Domingo de Soto, Releccion 'De dominio'. Edicion critica y Traducción, con Introducción, Apendices e Indices, por Jaime Prufau Prats (Universidad de Granada 1964), § 10 (100). For extended commentary, see Annabel Brett, Liberty, Rights and Nature: Individual Rights in Later Scholastic Thought (Cambridge University Press 1997).
} 
constant conflict and humans had to work in order to make their living. To protect themselves and to organise the attainment of their welfare, they had to divide things . First they created sovereign communities whose ruler had dominium over his subjects. This right was not absolute, however. Nor did it emerge from God - as Protestant heretics argued - but from the community itself. ${ }^{15}$ Political rights also extended to the Indians of the new world so that Spaniards had no right to intervene in the government of those communities without special justification. ${ }^{16}$ Alongside political communities, humans also used their freedom to create private property rights. These provided Vitoria and Soto the basis on which to discuss the law and the ethics of the novel commercial practices, questions such as just price, the morality of buying cheap and selling dear, of taking profit for exchanging currency and so on. ${ }^{17}$ What emerges from the work of the Salamanca theologians is a powerful theory of universal subjective rights that are the foundation both of political and private power and that can be defended - as Vitoria makes clear - by just war. $^{18}$

As a summary of the works of the Spanish theologians, the Jesuit Francisco Suárez (1548-1617), made express the point of the priority of subjective rights (of dominium) over other normative directives. The original situation of no political dominium and common property had been based on ("objective") natural law. This, however, had only a "negative" character which meant that it did not prohibit divisio rerum. (or as Vitoria put it, it had only the character of recommendation "concessio") ${ }^{19}$ Which is why it left "the matter to the management of men, such management to be in accordance with reason". 20 This however, posed an additional problem. If sovereignty and property were based on purely human acts, had natural law then nothing to say about revolution or theft? Well, no. Early on in his work Suárez introduced a distinction between ius as law and ius as subjective right of dominium. When natural law provides for the latter, it also provides for protection to whatever has been produced by it. After the intervention of divisio rerum natural law's non-derogable power now attaches to it, too. so that resistance to authority or stealing will

15 Although the prince's jurisdiction (dominium) over his subjects did originate from God, the transfer of that power to any particular prince took place through the community. See e.g. Francisco Vitoria, 'On Civil Power', in Political Writings, (A. Pagden and J. Lawrance eds., Cambridge University press 1991), 11. As Soto points out, civil power is created "mediante lege naturae per civilem republicam", in Domingo de Soto, De iustitia et iure Libri decem / De la justicia y el derecho en diez Libros (Intr. By P.V.Diego Carro, Spanish transl. by P.M. Gonzalez Ordonez, Madrid 1967), Bk IV Q IV A 2 (302b).

16 See especially Francisco Vitoria, 'On the American Indians', in Political Writings, 250-251.

17 Vitoria's views on private property and commercial expansion are discussed at length in his lectures. See Franciso de Vitoria, Comentarios a la Secunda secundae de Santo Tomás [ComST II-II], (Edition preparada por Vicente Beltrán de Heredia (Salamanca, 1934/1952) Tomo III (especially Q61 and 77-78, ). Parts of the commentaries are now published also as Francisco de Vitoria, Contratos y usura (Pamplona, EUNSA 2006). For a discussion of the role of Vitoria and Soto as founders of a private rights based econonomy, see further Cirilo Flórez Miguel, 'La escuela de Salamanca y los origins de la económia', in Francisco Gómez Camacho \& Ricardo Robledo (eds), El pensamiento económico en la escuela de Salamanca (Ediciones Universidad Salamanca, 1998), 124-144.

${ }^{18}$ Francisco Vitoria, 'On the American Indians', in Political Writings, 281-282, 'On the Law of War', id 295208. .

${ }^{19}$ Francisco Suárez, 'On Laws and God the Lawgiver, in Selections from Three Works (Vol II, Translation, G.L. Williams et al, Oxford, Clarendon 1944), Bk II, Ch XIV, § 14 (276-277). See also Quentin Skinner, The Foundations of Modern Politic al Thought, vol II (Cambridge University press 1977) 153-4. Vitoria Comentarions III Q 62 A 1 § 20 (77).

${ }^{20}$ Suárez, 'On Laws and the Lawgiver', Bk II, Ch XIV, § 6 (270) 
become an evil, subject to punishment. ${ }^{21}$ The "advantage" gained by fallen humanity from sovereignty and property is thus ratified by the binding force that natural law attaches to subjective rights. ${ }^{22}$

The subjective rights of the Spanish theologians helped to deal with the concerns of conscience among contemporaries triggered by violent expansion in the Indies and the widening network of global trade based on private profit-seeking. Even if freedom, equality and common ownership still remained ideals of natural law this did not mean, as the theologians carefully explained, that they would have actually prohibited the establishment political commonwealths with secular sovereigns, or the division of properties so as to enable the creation of world-wide contractual dependency networks. Sovereignty and property may not have their origin in nature but they were justified creatures of liberty and individual rights. As such they could be situated in the teleological frame of supernatural happiness that brought the varied forms of political and economic power under the ideological supervision of the Catholic church.

B. Rights, Protestantism and trade: Dutch 17th cetury

But the divided Habsburg realm of which Spain had become part in 1519 remained unable to maintain itself as a viable empire. With the Peace of Augsburg (1555), Protestantism found a permanent foothold in Germany and the revolt of the Protestant part of the Netherlands was consolidated by 1587-88 as Spanish attention was turned to England and France instead. By that time, the United Provinces had been able to establish themselves as a formidable military and economic power that was challenging Iberian dominance in the East Indies. ${ }^{23} \mathrm{~A}$ key part in the rise of the United Provinces was played by the civil ethos of Dutch Protestantism that united the interests of the state with the expansion of the overseas trade network that would account for the prosperity of the rebel provinces in the seventeenth century. The ideological background was provided by theories of resistance to tyranny that were also endorsed in the elaborate system of individual rights that lay at the heart of the writings of Hugo Grotius (1583-1645). Grotius came from a wealthy, well-connected family and had been trained in humanist and Stoic ideals. As a young man, he had been taken as apprentice and assistant to the Dutch Stadtholder Johan van Oldenbarneveldt in which role he had above all to mediate between the Protestant factions struggling for leadership in the young state. ${ }^{24}$ From 1604 he had also been engaged as legal advisor to the East India Company (VOC), developing an elaborate legal defence for the Company's violent operations against Portuguese and Spanish shipping that he had based on the

\footnotetext{
${ }^{21}$ Suárez, 'On Laws and the Lawgiver', Bk II, Ch XIV § 13 (275-276)

22 Suárez, 'On Laws and the Lawgiver', Bk II, Ch XIV § 13 (276).

${ }^{23}$ See e.g. Joachim Israel, Dutch Primacy in World Trade 1585-1740 (Oxford, Clarendon Press 1985).

24 Grotius' life is written in many places. A good condensed summary is W.J.M. Eysinga, Hugo Grotius. Eine biographische Skizze (Basel, Schwabe 1952).
} 
right of self-preservation (including the preservation of property) as the most important rule of natural law. ${ }^{25}$

In his main work De jure belli ac pacis (1625) Grotius followed Suárez by outlining three meanings of the expression "ius". First is ius as the object of justice - quod iustum est, - "that which is just". ${ }^{26}$ Like Suárez, Grotius then makes reference to a notion of ius that is synonymous to that of "law" - idem valet quod Lex. This describes any legal norm that is valid in the community concerned. ${ }^{27}$ But most interesting is the third (second in the order of presentation) notion of ius, one that exists as a "[q]ualitas moralis personae competens quad aliquid iuste habeandum vel agendum", a moral quality that human beings may "have" and carry with themselves wherever they go. This may exist in two modes, a "perfect" one that Grotius calls facultas and an "imperfect" one that he labels aptitudo. ${ }^{28}$ The former includes the power that humans have on themselves (personal liberty) as well as over one's property. Every human being has such facultas by virtue of merely being human. The network of relations between facultates is that which is covered by what Grotius calls "expletive" justice, the horizontal system of inter-individual relations characterized by the exercise of such subjective rights on the one hand, and everyone's duty to respect their use on the other. ${ }^{29}$

Such facultas contrasted with mere "aptitudo" that Grotius received from the Aristotelian notion of distributive justice (re-labelled "allocative" justice) that governed the vertical relations between public power and the subject of public power. Or in Grotius' own words:

"Attributive Justice, styled by Aristotle [...] Distributive, respects Aptitude or imperfect Right, the attendant of those Virtues that are beneficial to others, as Liberality, Mercy, and prudent Administration of Government." 30

This relationship is not properly speaking a legal relation at all. ${ }^{31}$ In other words, natural subjective rights belong to the realm of inter-individual justice and are both universal and binding as strict law, while entitlements based on attribution by the community, resulting from considerations of merit or charity, operative through administration and government of the community, are not legally binding. They may have moral or ethical force but do not ground any

\footnotetext{
${ }^{25}$ Hugo Grotius, Commentary on the Right of Prize and Booty (ed. \& intr. By MJ V Ittersum, Indianapolis, Liberty Fund 2006), Prolegomena (22-23).

${ }^{26}$ Hugo Grotius, The Rights of War and Peace, (Indianapolis, Liberty Fund 2005 [1625]) Bk I Ch I § III.I (136) Interestingly, the "just" is defined in a negative way - "that which may be done without injustice to an enemy", injustice being defined as what is "repugnant to a Society of reasonable Creatures", id. 27 Peter Haggenmacher, 'Droits subjectifs et système juridique chez Grotius,' in Luc Foisneau, Politique, droit et théologie chez Bodin, Grotius et Hobbes (Paris, Kimé 1997), 75.

28 Grotius, The Rights of War and Peace, Bk I Ch I § IV (138).

${ }^{29}$ Grotius, The Rights of War and Peace, Bk I. Ch I. $§$ V (138-9) and Preliminary Discourse, VIII (86).

30 Grotius, The Rights of War and Peace, Bk I Ch I § VIII (143)

${ }^{31}$ See Peter Haggenmacher, 'Droits subjectifs', 74.
} 
strong claim towards the State. Nor can they be enforced against facultates, especially against rights of dominium. ${ }^{32}$

In Grotius, then, we can find a well-developed system of individual (human) rights that not only justified Dutch commercial expansion but was specifically intended to create a universal system of rights, operated by contract, which it was the task of public power to facilitate and enforce. This Grotius expressly contrasted to any distributive scheme that public power might develop. As is well-known, Grotius also supported a "contractual theory of absolute sovereignty". ${ }^{33}$ Nature, he wrote, led humans to contract on the establishment of a political community. But although the foundation of civil community is in natural right, once the rights have been contracted, the life of the community is determined by sovereign power.

"For those who had incorporated themselves into any Society, or subjected themselves to any one Man, or Number of Men, had either expressly, or from the Nature of the Thing must be understood to have tacitly promised, that they would submit to whatever either the greater part of the Society, or those on whom the Sovereign Power had been conferred, had ordained". 34

In Grotius, then, a naturalist theory of individual rights is made to accomplish two things. One is the establishment and justification of a world-wide system of private commercial relations. The smooth operation of this system, as Grotius frequently remarks, is part of God's providential design to bring people together and to provide them with goods and happiness.

"God has not bestowed his Gifts on every Part of the earth but had distributed them among different Nations, that Men wanting the Assistance of one another, might maintain and cultivate Society. And to this End has Providence introduced Commerce". 35

Alongside this universal system that entitled the Dutch to penetrate maritime areas formerly held under Iberian monopoly, private rights likewise justified the Dutch rebellion against their former master, the Habsburgs. But once the rebellion was over - as it largely was by the time Grotius wrote - what was needed was doctrine of a strong centralised government that could keep in check the various religious factions that still continued to tear the young (and in some

\footnotetext{
32 To illustrate this distinction Grotius added in the 1631 edition of De jure belli ac pacis the story of Cyrus who had to adjudicate between two boys fighting over two coats. Cyrus decided to give the bigger coat to the bigger boy and the smaller coat to the smaller boy. In this he was corrected by his tutor. The task was not to attribute the coats in accordance with what Cyrus might have thought each had an entitlement according to allocative - that is to say, distributive - justice. The task was to give each boy the coat that belonged to him, over which he had the subjective right of dominium. The task of the State was not to distribute property according to some allocative principle but to give effect to the relations of dominium as they existed in the network of relations of commutative justice that governed the relationships of subjective right holders to each other. The King, in other words, was not entitled to intervene by an act of redistribution. Allocative justice could not be exercised over expletive justice. To do this was to violate the strict right the smaller boy had to the bigger coat. A relationship of rights is prior to any relationship of attribution. The King may tax his subjects for the good of the community but not in order to distribute wealth among his subjects.Grotius, The Rights of War and Peace, Bk I Ch I § VIII.2 (146-147).

33 Martin Loughlin, Foundations of Public Law (Oxford University Press 2010), 75.

34 Grotius, Rights of War and Peace, Preliminary Discourse XVI (93)

35 Grotius, The Rights of War and Peace, Bk II Ch II § XIII (444).
} 
way quite artificial) state apart. A universal empire of private commercial relations, and a firm notion of state sovereignty - both were received by Grotius from a sophisticated argument from individual (human) rights. Because those rights were no longer based on a an overall teleology of supernatural happiness in the afterlife, as they had been with the Spanish writers (whom Grotius closely followed), this deprived the church from its position as the final authority on their use.

C. Rights, Empire and Revolution: $18^{\text {th }}$ Century

The vocabulary of rights provided a convenient instrument to address both European statebuilding and expansion that could only with difficulty be brought under larger theological or imperial frames. The idea of a ownership of one's freedom, understood as a faculty, would easily extend to the right to contract over the establishment of a commonwealth at home as well as to acquire and dispose of property everywhere. ${ }^{36}$ In both Catholic and Protestant realms ideas about objective justice - justice as the object of what we do - were in the course of $16^{\text {th }}$ and early $17^{\text {th }}$ centuries translated into subjective (dominium-) rights that would be natural to all humans and applicable across the world through the operation what was often called the jus gentium. ${ }^{37}$ In the Spanish scholastics and their Jesuit followers as well as in Grotius, Melanchton and Calvin's disciples subjective natural rights would provide building-blocks for the justification of civil power in political communities at home as well as a conception of what Suárez called "respublica humana" within which individual right-holders could freely travel and transact on their properties everywhere. In Spain, the theologians' principal concern had been to develop a meticulously up-to-date casuistry for the moral assessment of new types of activities in which Christians had been participating as a result of conquest and commercial expansion. In the United Provinces, Grotius removed this casuistry from its original theological context and used it as part of a system of (subjective) natural rights in which providence would see to the ultimate compatibility of the pursuit of self-preservation with an all-encompassing sociability. As the latter's Saxon follower Samuel Pufendorf (1632-1694) would explain, with human beings who are both weak and self-loving, the rational conclusion is to become sociable - that is to say, to set up social institutions whose official justification would always back to the original liberties of their founders. ${ }^{38}$ Whether natural liberty encompassed also the right of selling oneself to slavery (as the apologists of Portuguese slave trade explained) was a disputed question. But most natural right went into justifying firm political rule over confessionally split societies with the objective of salus publica.

\footnotetext{
${ }^{36}$ See further, Anthony Pagden, 'Human Rights, Natural Rights and Europe's Imperial Legacy', 31 Political Theory (2003), 171-199.

${ }^{37}$ See especially Annabel Brett, Changes of State

38 Samuel Pufendorf, 'On the Law of Nature and of Nations (1672), Bk II, Ch 3 § 14-24, in Craig L. Carr \& Michael J. Seidler, The Political Writings of Samuel Pufendorf (Oxford University Press 1994), 151-157.
} 
In England, the coincidence of John Locke's (1632-1704) influential writings on individual rights with his interest and advocacy of English colonization in the Americas has long been known. There probably is no reason to attribute to Locke the kinds of imperialist designs that would emanate from ideas of racial supremacy or progress. ${ }^{39}$ The main target of his Two Treatises was the arbitrary absolutism of the theory of divine kingship against which Locke set up all individuals' universally valid natural rights that would, unlike in the continental traditions, have a live role also in the government of political commonwealth. ${ }^{40}$ Nevertheless, the criteria through which he derived rights on property on land and sovereign authority over a community, somehow always eluded the Indians. Native Americans may indeed have shared humanity and natural rights equally with Englishmen. But this did not mean that their agricultural or hunting activities would have provided them exclusive entitlement to lands desired by Englishmen or that their communities would have qualified as political commonwealths with sovereign rights against foreign intruders. ${ }^{41}$

Locke instituted the $18^{\text {th }}$ century practice of using the contrast of "slavery" and "rights" as a combat call against absolutism and the divine rights of kings and in favour of a commercial society whose backbone would be a vibrant merchant elite. Therefore, by far the most important (universal, human) right in is system was the right of private property - even if it always remained subject to some limitation by its having been instituted by God for the preservation of individuals and humankind at large. ${ }^{42}$ Human beings enter society, Locke famously wrote, for "the enjoyment of their properties in peace and safety". ${ }^{43}$ From this he received a conclusion quite opposite to that of Grotius and many later naturalists, namely that the right was not exhausted with the social contract but remained valid as a right against the legislature, prohibiting rule "by extemporary arbitrary decrees" as well as the taking of property, including through taxation, without consent. ${ }^{44}$ To lose one's natural rights in a political community would count as enslavement - and it would be absurd to think that originally free individuals would ever have accepted the institution of political sovereignty for such purpose.

In post-Westphalian Germany natural law would legitimate the post-confessional state. Following Pufendorf, Christian Thomasius and other jurists at such early enlightenment universities as Halle or Göttingen, postulated a state of nature in which free individuals contracted among themselves over the establishment of political communities and setting up (usually absolutist) rulers to govern them ("Gesellschaftsvertrag" and "Untewerfungsvertrag").

\footnotetext{
39 David Armitage, 'John Locke: Theorist of Empire?', in Sankar Muthu (ed), Empire and Modern Political Thought (Oxford University Press, 2012), 84-111.

40 John Locke, Two Treatises of Government (London, Everyman's 1924), e.g. 2.169-174 (204-206).

41 For the classic discussion, see James Tully, An Approach to Political Philosophy: Locke in Contexts (Cambridge University Press 1993), 137-176.

42 Locke, Two Treatises, 2.31 (131-132). See further James Tully, A Discourse on Property. John Locke and his Adversaries (Cambridge University Press, 1980), 121-124.

${ }^{43}$ Locke, Two Treatises, 2.134 (183).

${ }^{44}$ Locke, Two Treatises. 2. 136, 138, 140 (183, 185, 189).
} 
Until the 1770s and 1780s natural rights were understood above all in terms of the original liberty that was channelled to State institutions for the realization of the functional objectives of salus publica and state purpose (Staatszweck). They remained, however, usually without juridically binding force against the ruler. Towards the end of the century constitutionalists began to argue for the normative force of rights even within state, through the spread of the rhetoric of freedom (Freiheit) in legal and political discourse, inspired by the revolutionary experiences in America and France. ${ }^{45}$ This did not necessarily underwrite their revolutionary character. In March 1791 the Imperial Chancellery in Vienna, for example, published a statement to the effect that it was evident that all individuals enjoyed human rights but that they became no better from being shouted by mobs: "the rights of human beings and of citizens are nowhere better secured than in the heart of [the Emperor] Leopold". 46

The natural rights idiom had become familiar in France especially after the translations of Grotius and Locke, as well as the writings of Jean-Jacques Burlamaqui (1694-1748), had became available in the 1720s and 1730s. French jurists soon learned to pepper their arguments with points about the rights of their clients. ${ }^{47}$ However, unlike in Germany, natural law never became a university discipline in France. 48 This was in part because of its association with Protestantism and Huguenot policy, in part owing to what the society of the salon viewed as its pedantic scholasticism. Voltaire and Rousseau understood it as conservative, if not strictly reactionary. On the other hand, literary invocations of a golden age were nevertheless often expressed in the languages of "humanity" and "natural liberty" so as to attack the ills of the old regime. ${ }^{49}$ Diderot, Montesquieu and Rousseau all had a complex debt to the natural law tradition. It was only later in the century that individual natural rights arose as a significant topos. One context in which it did so was that of the economic theories of the Physiocrats who as part of their criticisms of mercantilism and advocacy of free trade highlighted the rights of contract and property as the only acceptable foundation of modern economy. Nothing puts more clearly the universalist pathos of the new doctrine of natural rights than the brief essay by a leading "Économiste", Pierre Samuel Dupont de Nemours (1739-1817), later Inspector General of Commerce, and a tireless propagator of free trade in France and later in the United States. ${ }^{50}$ He began with the anti-

\footnotetext{
45 For a full discussion of the contrast between "old" (1648-1770) and "new" (1770-1815) uses of natural law and natural rights in Germany, see Diethelm Klippel, Politische Freiheit und Freiheitsrechte im deutschen Naturrecht des 18. Jahrhunderts (Paderborn, Schönigh, 1976).

46 "die Rechte der menschen und Bürger sind nirgends sicherer bewahrt als im Herzen Leopolds (II)", Wilhelm Brauneder, 'Vom Nutzen des Naturrechts für die Habsburgsmonarchie”, in Diethelm Kilippel, Naturrecht und Staat. Politische Funktionen des europäischen Naturrechts (Munich, Oldenbourg 2006), 162. , 47 On the spread of natural rights in French legal advocacy (with statistical data on legal process in Dijon), see Wolfgang Schmale, 'Naturrecht und Staat in Frankreich', in Diethelm Klippel, Naturrecht und Staat: Politische Funktionen des europäischen Naturrechts (Munich, Oldenbourg, 2006), 94-96.

${ }^{48}$ See e.g. John Heilbron, The Rise of Social Theory (Cambridge, Polity 1995), 42-42-46, 67-68.

${ }^{49}$ See Dan Edelstein, The Enlightenment. A Genealogy (University of Chicago Press 2011), 58-59; Heilbron, The Rise of Social Theory, 96-100. And further Dan Edelstein, The Terror of Natural Right. Republicanism, the Cult of Nature \& the French Revolution (Chicago University Press 2009).

50 For a useful discussion, see Martin Giraudeau, 'Performing Physiocracy. Pierre Samuel Dupont de Nemoius and the Limits of Political Engineering', 3 Journal of Cultural Economy (2008), 225-242.
} 
Hobbesian dictum that a natural society existed between humans that was formed out of their needs and interests and was prior to any convention between them.

"Dans cet état primitive les hommes ont des droits et devoirs réciproques d'une justice absolue parce qu'ils sont d'une nécessité physique \& par conséquent absolue pour leur existence. $»^{51}$

The natural society of humans was expressed in their reciprocal rights and duties that good government would put in a harmonious relationship. In the natural society all humans had the liberty to pursue their subsistence; they also had the right of property over things they had achieved through their labour. The rights were anterior to any convention and could not be taken away by convention, either. In Dupont's dramatic formulation, the human sovereign was incapable of legislating anything new - "car les lois sont toutes faites par la main de celui qui créa les droits \& les devoirs". ${ }^{2}$ Positive laws were powerless to contradict the laws of freedom and property; all they could (and should) do was to declare their content and to enforce them. ${ }^{53}$

But if individual rights operated well as a claim by the "moderns" to support the move to a commercial society, they were equally available as a republican instrument to support political renewal on the left. Abbé Gabriel Bonnot de de Mably (1709-1785),, one-time friend of Rousseau's, the author of an early commentary on Droit public de l'Europe, turned into a fierce critic of the old regime in a dialogue with the fictitious Englishman "Lord Stanhope", putting forward a radical project of political renewal in pursuit of individual political rights after the English model. To the Frenchman who agreed on the basic rights but voiced his doubts about the ability of Frenchmen to make constructive use of them, "Stanhope" responded that there was even a duty on every patriot to make use of their rights and not to rely on authority; rights crystallised in active citizenship and a novel constitution had to give room for activism as the core of a system of republican rights. ${ }^{54}$ The French revolutionaries had read their Mably, their Rousseu and their sentimental literatures in which the rhetoric of rights flourished - deciding to preface the constitution they had decided to adopt with a declaration of rights, a task they thought to perfect first in a few heated days in August 1789 but to which the conduct of the revolution itself forced them to return in 1793 and in 1795.

\footnotetext{
51 Pierre Samuel Dupont de Nemours, De l'origine et des progrès, d'une science nouvelle (London, Desaint 1768), 17-18.

52 Dupont, De l'origine et des progrès, 30.

53 Hence there was no reason to separate between legislation and enforcement; valid legislation was always also enforcement of the prior system of natural rights and obligations. Dupont, De l'origine et des progress, 31-32. For the absolute natural rights doctrine of the leading jurist among the Physiocrates, Paul-Pierre Le mercier de la Rivière, see Martti Koskenniemi, 'The Public Law of Europe', in H. Lindemann et al (eds), Erzählungen vom Konstitutionalismus (Baden-Baden, Nomos 2012), 61-63.

${ }^{54}$ Abbé de Mably, Des droits et des devoirs du citoyen (Paris, Lacombe 1789). For the context, see Keith Michael Baker, 'A Script for the French Revolution: The Political Consciousness of Mably', in Inventing the French Revolution. Essays on French Political Culture in the Eighteenth Century (Cambridge University Press 1990), 88-91.
} 
The drafting of the Declaration on the Rights of Man and Citizen by the French National Assembly and Convention, as Marcel Gauchet has shown, was intended to accomplish a number of paradoxical objectives. It was to provide a founding to a novel power, the Nation representing "all" - while simultaneously laying the limits of that power vis-à-vis the citizens. As a result, the debates that were repeated, almost verbatim, in 1789, 1793 and 1795 on the relation of "rights" to "duties", and of freedom-rights to the rights of "assistance" from the Nation defined the pattern of future parliamentary politics everywhere in Europe. Fluctuating between more and less radical and conservative tendencies, the deputies often found refuge in ambivalent formulations that linked rights with corresponding obligations or stressed that "free individuality" was possible only in a society that provided equal resources to everyone. A founding on individual freedoms, for Jacobin patriots, could only mean complete subservience of everyone to the Nation - while the express inclusion of a part on individuals' “duties" would, for Thermidorean revisionists provide a definite sphere for the roles of each. The deputies grappled with formulations that derived the rights - and thus the constitution they would preface - from nature and from society, thus suggesting that political problems were ultimately philosophical - while anxiously debating the concrete institutional consequences the proposed formulations would imply. Their bewilderment about the intellectual problems in the task they were trying to accomplish was reflected in the proposal, still ventilated on the last day of the Thermidorean drafting process in 1795 , that at issue was not the adoption of a "law" at all, but a "basis of the social contract", a declaration or a "theory". 55

The wisdom and the paradox of this last suggestion arose again with the passing of the Universal Declaration of Human Rights in 1948 where one of the principal post-war proponents of the idea of a declaration, Hersch Lauterpacht, lamented that the rights were included in am instrument that was a mere General Assembly resolution and as such not binding as law - in fact that the passing of the declaration at the General Assembly provided the only conceivable context in which UN member states could conceivably stand up to declare, with all due solemnity, that they loved these rights, and were not bound by them. ${ }^{56}$ But what if the rights had been made the object of a treaty? At that point, they would have become subject to all the problems concerning national ratification and reservations as well as the interpretative principles of the 1969 Vienna Convention on the Law of Treaties; their amendment and indeed their validity would have been anchored in the fluctuations of UN diplomacy. Surely to exist as the foundation of politics, they should not be understood as an effect of political interests and bargains...

\section{II: THE POWER AND WEAKNESS OF RIGHTS: SOME CONCLUSIONS}

\footnotetext{
55 Marcel Gauchet, La Révolution des droits de l'homme (Paris, Gallimard, 1989), 315.

${ }^{56}$ Hersch Lauterpacht, International Law and Human Rights (London, Prager 1950).
} 
The above discussion highlights the almost infinite variability of the contexts in which the rightsvocabulary may be available to support some causes or preferences against others. In the United Nations, for example, the direction of rights-activity has fluctuated from a Western stress on civil and political rights, to an "originalist" concern over the "indivisibility" of civil and political rights and economic and social rights, to a 1970s-1980s post-colonial "revisionism" that read rights as instruments for economic justice and "development", and finally into an alignment in the 1990s with the preferences of UN human rights treaty bodies..$^{57}$ As the above history has shown, in the aftermath of the Protestant rebellion, rights would both support and challenge the power of religious institutions. In early modern Germany, they were invoked to defend individual liberty but also to retrench a firm central power assigned to look for the security and happiness of the citizens. During the European enlightenment rights supported revolution but also state-building and then, as now, the two things have often gone together. As much as rights have defended individuals against their communities, they have also underwritten the community's power to demand that individuals respect its traditions: liberalism, republicanism and even socialism have thrived on rights.

Because rights are everywhere, it is impossible to use them to show a single line of progress. It is a fantastic but significant fact that although "slavery" had been a continuously reiterated trope of the French enlightenment, standing for everything the enlighteners were against, that discourse coexisted quite peacefully with the enslavement of Africans in the French West Indies throughout the $18^{\text {th }}$ century, up into and beyond the revolution of 1789. In fact, the number of slaves imported to the Caribbean was never higher than in the last quarter of the $18^{\text {th }}$ century when it rose to 419,500. 58 The call to break the "chains of serfdom" meant emancipation at home, not putting an end to colonial slavery. Rousseau, for example, had nothing to say in the whole of his career about system of enslavement in the Caribbean that were the source of the sugar he enjoyed. ${ }^{59}$

The coexistence of rights with enslavement and other kinds of massive suffering is of course not a thing of the past but a palpable aspect of the present. As Susan Marks has pointed out, between the 1990s and now the tone of rights-speech has moved from romance to tragedy, not only because there has not been "enough" rights but owing to problems (such as those surveyed above) within rights themselves. ${ }^{60}$ To explain this, it may be useful to start with acknowledgment that the common discourse about rights being "universal, inalienable and indivisible" is an

\footnotetext{
57 For aspects of this history, see Daniel J. Whelan, Indivisible Human Rights. A History (University of Pennsylvania Press 2010).

58 The number is from Kwame Nimako \& Glenn Willemsen, The Dutch Atlantic. Slavery, Abolition and Emancipation (London, Pluto Press 2011), 22. See further Robin Blackburn, The Overthrow of Colonial Slavery, 1776-1848 (London, Verso) , 161 and generally Yves Benot, Les lumières, l'esclavage, la colonization (Paris Découverte 2005),

${ }^{59}$ Susan Buck-Morss, Hegel, Haiti and Universal History (University of Pittsburgh Press 2009), 29-34.

${ }^{60}$ Susan Marks, Human Rights in Disastrous Times', in James Crawford \& Martti Koskenniemi, The

Cambridge Companion on International Law (Cambridge University Press, 2011),
} 
intellectual stopgap and a political dead end. It looks towards a world of harmony where the right of all humans - that is to say the preferences of all - would organise themselves coterminously. Neither conceptual logic nor historical experience supports such a view. Since Kant, and perhaps earlier, it has been an aspect of a rationalist imagination whose political force may have been formidable, but which has lent itself to whatever cause and agenda. Because it denies of the reality of a conflicts, explaining them as misunderstandings of everyone's real preferences, it has complicated, instead of facilitated, their resolution. Between sheer arbitrariness and cynicism, it has opened the door for the bureaucratic management of rights through the ubiquitous practices of "balancing" whose criteria are received from an institutional bias that cannot be articulated by the rights whose limit and content it sets.

And yet is also is obvious that behind every (subjective) human right lurks an "objective" right that involves some idea of good society where the preference indicted by the right is supposed to flourish. Freedom speech is meaningful only in a society with a well-functioning and accessible system of communications - but what it means to have such is an issue of policy. To make a reality of civil and political rights involves more than periodic elections and often - as the "Arab Spring" suggests - wholesale transformation of societies where some will win, others lose. And of course economic and social rights refer back to contested views about just distribution, techniques of economic management and even the objectives to be attained. Only by reference to such larger - one is tempted to say "structural" - objectives and values it is possible to finally prefer some rights (and their attendant political projects) to others.

Marxian critics used to argue that it was a big problem with rights that they tended to prefer individuals over groups, positing the egoistic and alienated individual as the social ideal to which everyone should aspire but which then perpetuated the exploitative relations of capitalist society. ${ }^{61}$ Although the power of that critique has not been exhausted, it is nevertheless the case that the spread of rights to cover goods of a collective type, including economic and social rights (however lacking their implementation), has mitigated that concern and expanded the range of preferences rights-talk can be used to defend. More important, perhaps, is the way that talk focuses on things we "have" or (to follow Grotius) "faculties" we "possess", seems obsessively concerned over identities rather than the structural determination of those identities. Rights may support our capacity of exercise a religion we profess, to express and opinion or to support a party we prefer, to use a property we have, that is to say, to be "true" to ourselves and our life projects. But it is blind to the conditions within which we come think of ourselves as "religious" in a particular way, members of a party, property-owners or persons with specific opinions. This, I think, is an important aspect of the intellectual dead end that rights bring with them. They claim to protect our (person, group) identities and preferences without ever questioning how we came to have them. They are so close, so intimate to our assumed selfhood that they make it impossible

${ }^{61}$ See Karl Marx, 'On the Jewish Question', in Marx, Early Political Writings (J. O’Malley ed. Cambridge University Press 1994), 41. 
for us to situate ourselves in any larger context - especially a context of an ubiquitous identityproducing power.

It is here, I think, that historical studies of the uses of rights-vocabularies become helpful. Raymond Geuss recently pleaded against abstract political theory that focused on ideal states and moral commitments and in favour of historically informed studies of the uses of political concepts - such as "human rights" -in actual controversies. For, as he put it,

"[t]he reasons for why we have most of the political and moral concepts we have (in the form in which we have them) are contingent, historical reasons, and only a historical account will give us the beginnings of understanding of them and allow us to reflect critically on them rather than simply taking them for granted". 62

Historical studies of rights, I would like to claim, have two kinds of properties that break the intellectual dead-ends involved in abstract philosophical exercises around the meaning or relationships of rights. They open up those larger contexts in which we can see rights perform (or failing to perform) social functions by advancing some causes against other causes, supporting interests, projects and programs that have real importance to the actors in those historical dramas that we are studying. They show that rights not only overlap and conflict but that this is often their very point. The most important human violations do not just "happen" to some people but are logical and accepted consequences of particular policies. They cannot be attributed to impersonal forces but operate as "planned misery" that also account for the wealth and power of other people. ${ }^{63}$ Focusing in this way from victims to perpetrators is easiest in historical studies that locate rights as aspects of imperial or commercial expansion, religious war, colonial exploitation, revolution or retrenchment, state-building and so on. Chronology helps to attain distance and genealogy makes that which happened seem not necessary at all, but the contingent results of struggle and choice. But historical studies also illustrate the process whereby people attain certain identities and preferences - they come to think of themselves as "Catholics" or "Protestants", "Indians" or "Turks", men and women. Early scholastic thought understood dominium fundamentally as individual's ownership of their identity and used the attendant notion of "liberty" to justify the new social roles that $16^{\text {th }}$ century Spaniards were adopting in a commercially and militarily expanding Europe. Similarly, the $18^{\text {th }}$ century natural rights-concept opened for Europeans the way to think of themselves as virtuous republicans or cosmopolitan operators in a commercial "system", choices and subject-positions within which increasingly minute differentiations counted for the European modernity that soon became that of "modernity" tout court. The new histories of human rights, I think, are valuable in marking out how the structure of that modernity came about but also how it became invisible by the fact of attention being directed to individuals, their preferences and projects, their identities and

62 Raymond Geuss, Philosophy and Real Politics (Princeton university Press 2008), 69.

${ }^{63}$ Susan Marks, 'Exploitation as an International Legal Concept', in Marks (ed), International Law on the Left. Re-Examining Marxist Legacies (Cambridge University press, 2008), 281-307; id. 'Human Rights and Root Causes', 74 Modern Law Review (2011), 57-78. 
"rights". In these ways history performs a classical critical service. It situates rights-vocabularies in the contexts of their uses, drawing out the winners and the losers and situating both in the larger structures that determine for each, the trajectory that makes them such. 